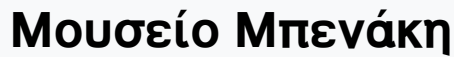

Tóp. 1 (2001)

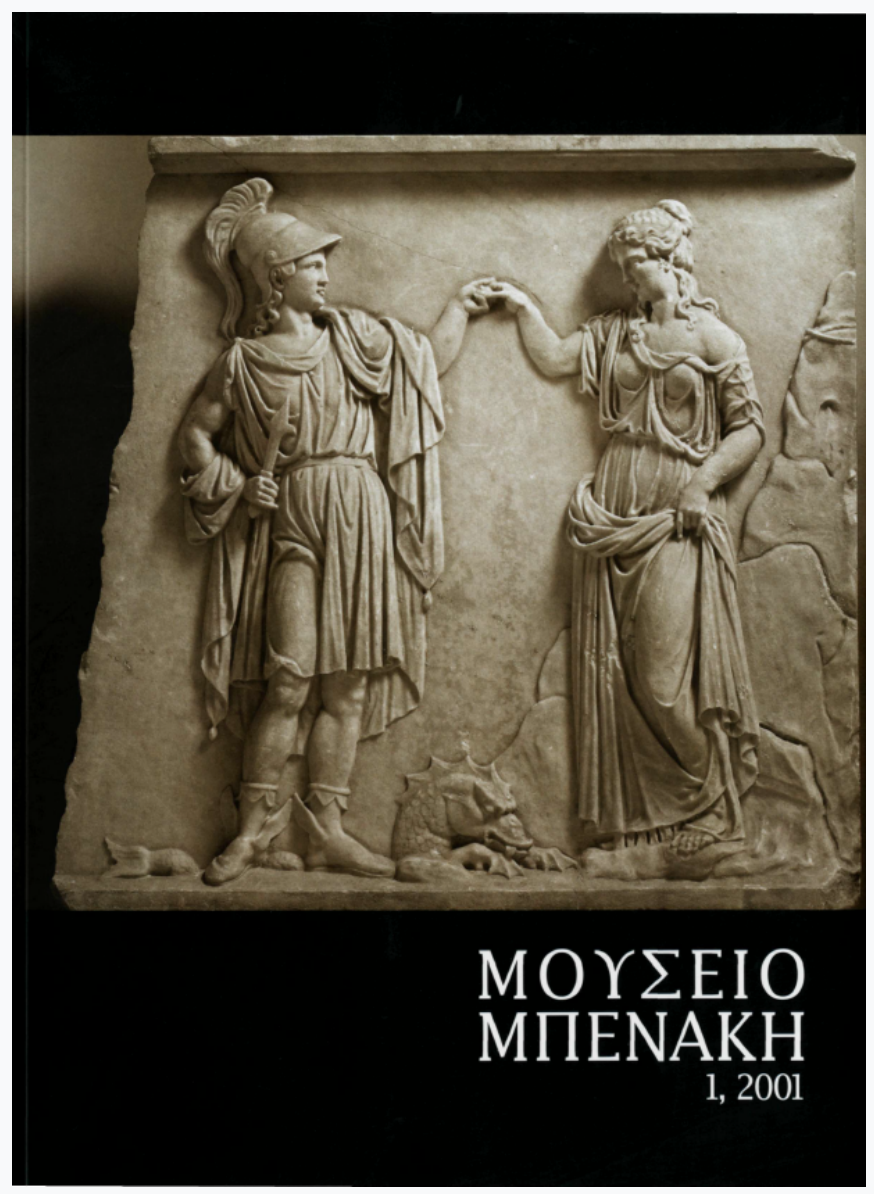

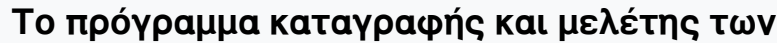
aveıßó̀ $\omega v$

Maria Vassilaki

doi: $10.12681 /$ benaki.18329

Copyright $\odot$ 2018, Maria Vassilaki

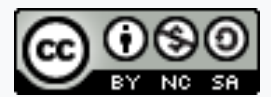

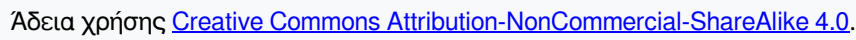

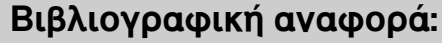

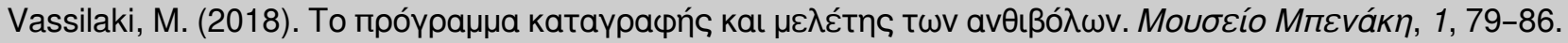
https://doi.org/10.12681/benaki.18329 


\section{Working drawings: research and study programme}

THE CONDITIONS WHICH DEVELOPED after the fall of Constantinople in 1453 and the disintegration of the Byzantine Empire led to the transformation of Crete, under Venetian occupation since the early 13th century (1210), into the major artistic centre of the Orthodox world. Large painters' workshops were established in the island's urban centres - in particular Candia, the capital - and they undertook commissions for icons in substantial quantities. To meet this increased demand they were suitably organised to take account of both the human and the technical resources available. An examination of the methods by which Cretan painters of the 15th, 16th and 17th centuries reproduced and transferred their iconographic material from one icon to another shows that this was done with the aid of working drawings (anthivola), which allowed iconographic themes to be copied identically, down to the last detail.'

The process of making exact reproductions of the subject matter of an icon by imprinting them on specially prepared paper is described in detail in the Painter's Manual by Dionysios of Fourna, compiled on Mt Athos between 1728 and $1733 .{ }^{2}$ Dionysios instructs painters who wish to make an imprint of the representation of a saint to go over the contours with black colour and garlic juice, and then the details of the face and drapery with red colour and garlic juice. ${ }^{3} \mathrm{He}$ tells them to take a sheet of paper of the same dimensions as the image to be copied, soak it in water and place it between other sheets of paper so that some of the liquid is absorbed; then to place the damp paper on the icon and hold it there firmly until the representation is imprinted. This is the method by which "imprinted cartoons" (ektypa antivola) were made (fig. 1), and these in turn could be used to produce a large number of "primed" or "pricked cartoons" (diatrita anthivola) with the aid of a pointed object (fig. 2). The painter placed the pricked cartoon on the icon's gesso priming and, by sprinkling powdered charcoal over the holes in the cartoon, caused the design of the icon to appear on the white priming. It was then incised to avoid erasure during the painting process.

It is clear from documentary evidence that Cretan painters possessed working drawings from the 15 th century onwards. The earliest reference is found in the will of the painter Angelos Akotantos, ${ }^{4}$ drawn up in $1436,{ }^{5}$ in which he bequeathed his drawings to his unborn child should he be a boy and wish to learn the art of painting, and otherwise to his brother John, who was also a painter.

The use of transfer drawings was apparently introduced into icon-painting by Cretan painters, who adopted a practice already known in Italian workshops ${ }^{6}$ and it seems to have become well established by the end of the 15th century. This development was facilitated by certain factors prevailing on the Venetianheld island of Crete, such as:

1. The mass-production of Cretan icons, which led to a division of labour within or among workshops and a standardization of their work

2. The establishment by the 15 th century of a series of iconographic subjects which became extremely pop- 


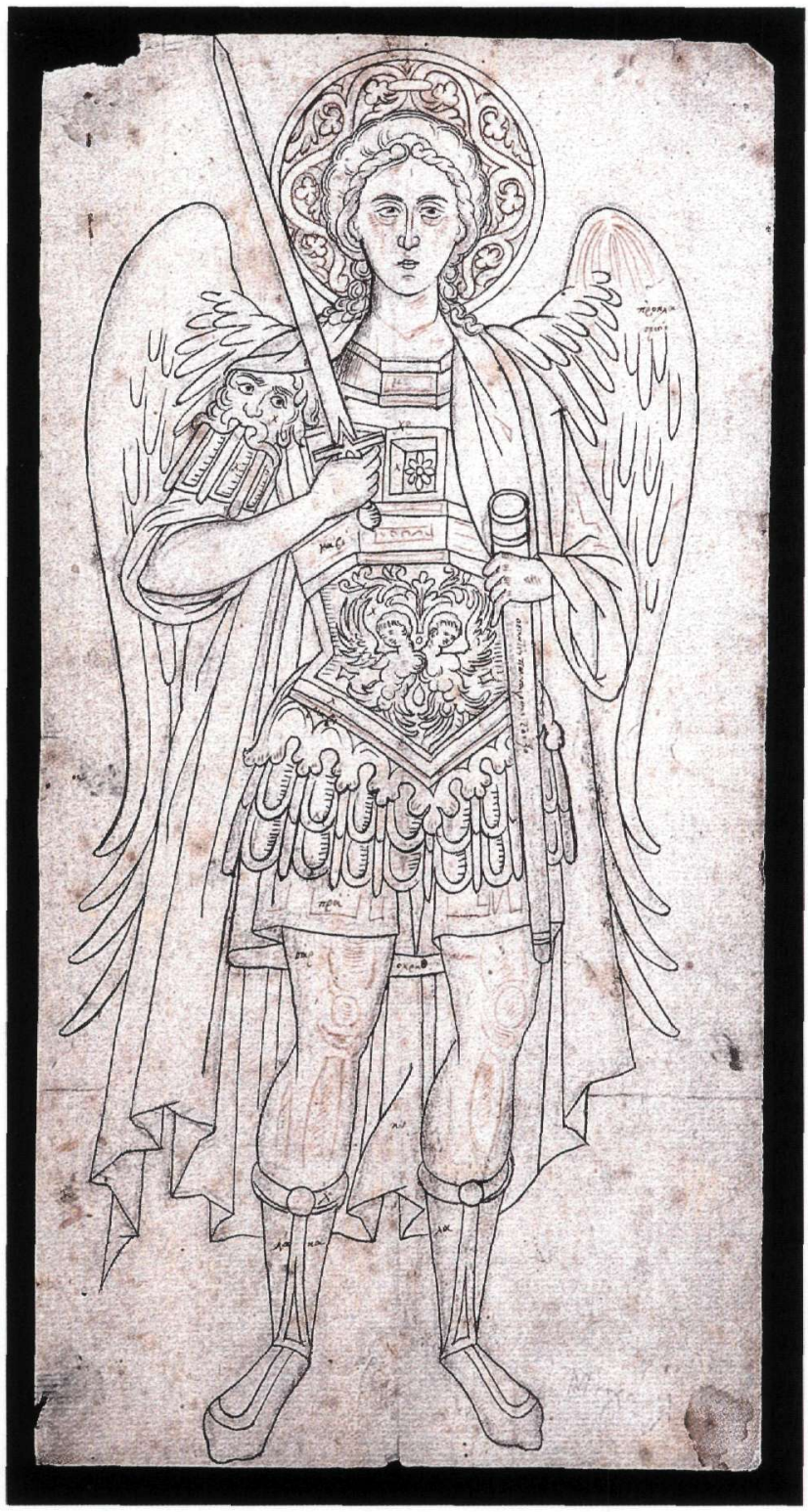

Fig. 1. Imprinted cartoon of the Archangel Michael. Athens, Benaki Museum 33147 (photo: K. Manolis).

Fig. 2. Pricked cartoon of the Meeting of Joachim and Anne. Athens, Benaki Museum 33205 (photo: K. Manolis). ular and were copied faithfully by the following generations of painters and

3. The availability and wide circulation of paper.

The Department of Paintings, Prints and Drawings at the Benaki Museum owns two very important portfolios of working drawings. ${ }^{7}$ The first was purchased by Antonios Benakis himself from the dealer Theodoros Zoumboulakis in the mid-1940's, ${ }^{8}$ and contains 372 sketches for wall paintings associated with Mt Athos (fig. 3). The second belonged to the well-known Byzantinist Andreas Xyngopoulos, who acquired it through the dealer Demosthenes Staikos, and it was bequeathed to the Benaki Museum on his death in 1979; this consists of 464 sheets, most of which are pricked cartoons to be used for icons (fig. 4. 5). The late Laskarina Bouras was involved in the study of these portfolios ${ }^{9}$ and after her death I undertook the continuation and completion of the work with the ultimate aim of publication in the form of a scholarly catalogue. This study is being carried out with the financial support of the A. G. Leventis Foundation and the J. F. Costopoulos Foundation.

The working drawings were originally recorded on traditional card indexes and later electronically. The definition of the fields for the electronic cards was made with the collaboration of the Documentation and Systems Department of the Benaki Museum. Our aim was to establish retrieval of information, which would allow the collection of statistical data on the use of working drawings. All the drawings have also been digitised.

The study of the Benaki Museum's working drawings allowed us to penetrate below the paint surface of the icons and examine their technical background. ${ }^{10}$ If we wish to establish whether a drawing has been used for a particular icon, X-ray photography enables us to locate the incised design still visible on the icon's gesso priming. It can also be identified through infra-red reflectography, as long as traces of charcoal remain on the priming; the latter method, particularly well established in the field of European art, has produced impressive results. ${ }^{11}$ The examination of icons by infra-red reflectography is being undertaken in collaboration with the Museum's Department for the Conservation of Works of Art, and specifically with Mr Stergios Stassinopoulos.

An important part of the study is devoted to identify- 


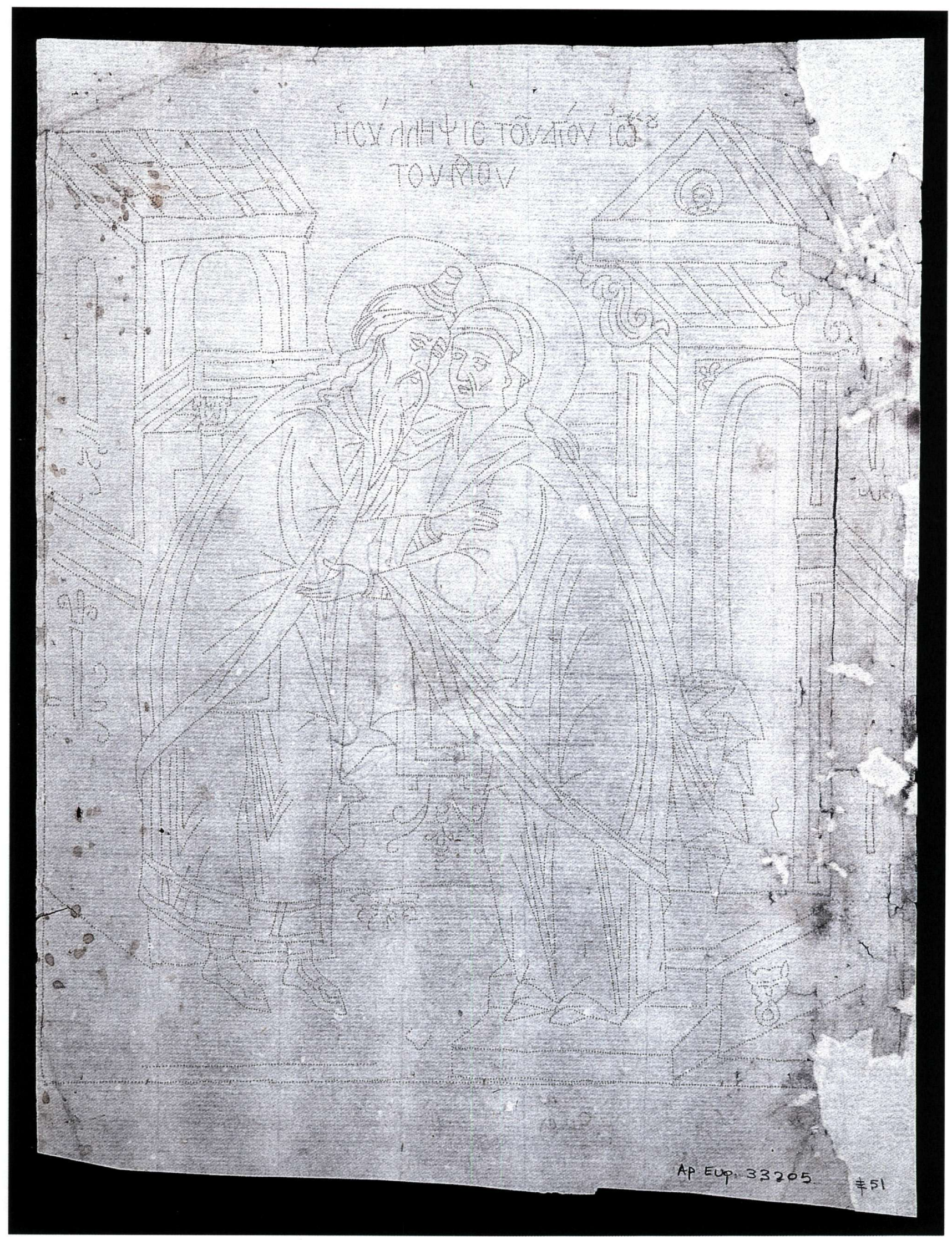




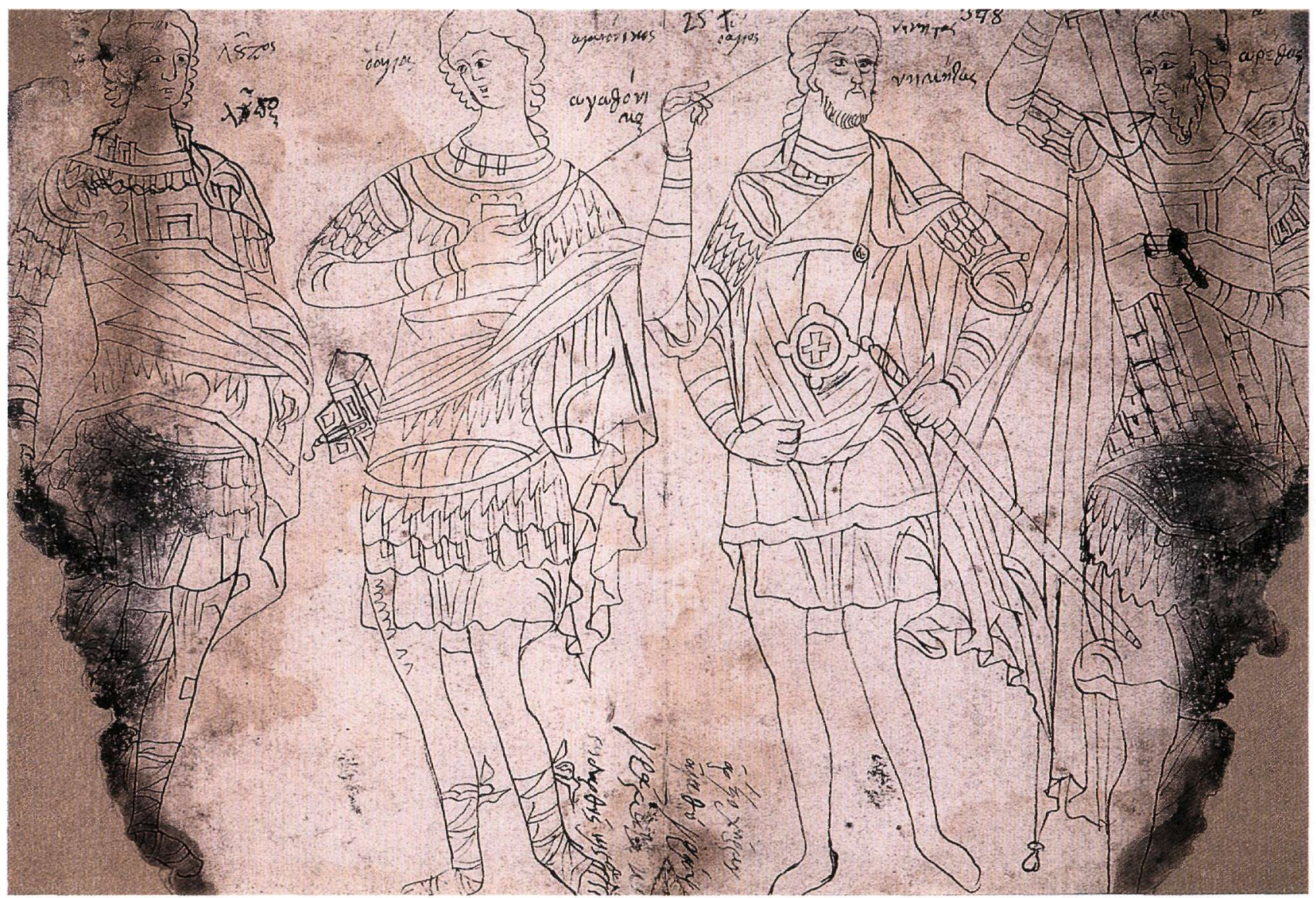

Fig. 3. Working drawing of Military Saints. Athens, Benaki Museum 25544 (photo: K. Manolis).

Fig. 4. Imprinted and pricked cartoon of the Nativity. Athens, Benaki Museum 33242 (photo: K. Manolis).

ing the watermarks which are often preserved in the paper of the working drawings. These marks are created when the paper is still in pulp form, with the aid of a design made of wire which is set into the mould. ${ }^{12}$ As a result the paper becomes thinner and semi-transparent at this point, and the watermark is visible when the paper is held up to the light. Watermarks were introduced in the late 13th century at Fabriano in Italy, and from there they spread to paper mills throughout Europe where they were used as trademarks in the form of symbols, letters, names, initials, insignia etc. Their importance in dating paper was recognised very early on and the first systematic records of watermarks, together with the circulation dates of the paper in which they are imprinted, began to appear as early as the beginning of the 20th century. ${ }^{13}$ Establishing the date of the watermark and the year of circulation is the most reliable method of dating a sheet of paper and by extension the same comment applies to the dating of a manuscript or a sketch for a painting, since this is done by dating the actual sheet of paper on which they were drawn. It is therefore especially important for the recording of the watermark to be as accurate as possible, so that the paper mill and the year of manufacture can be investigated and identified. In recent years considerable research has been carried out in this field with the aid of the most upto-date technology, and studies made at the Department of Prints and Drawings at the British Museum, the Louvre and the Rijksmuseum, Amsterdam have shown that the best results are obtained by using the beta-radiography method, which requires very basic equipment and a source of beta radiation. This is the first time that such systematic recording, classification and study of the watermarks of a large sample of paper 


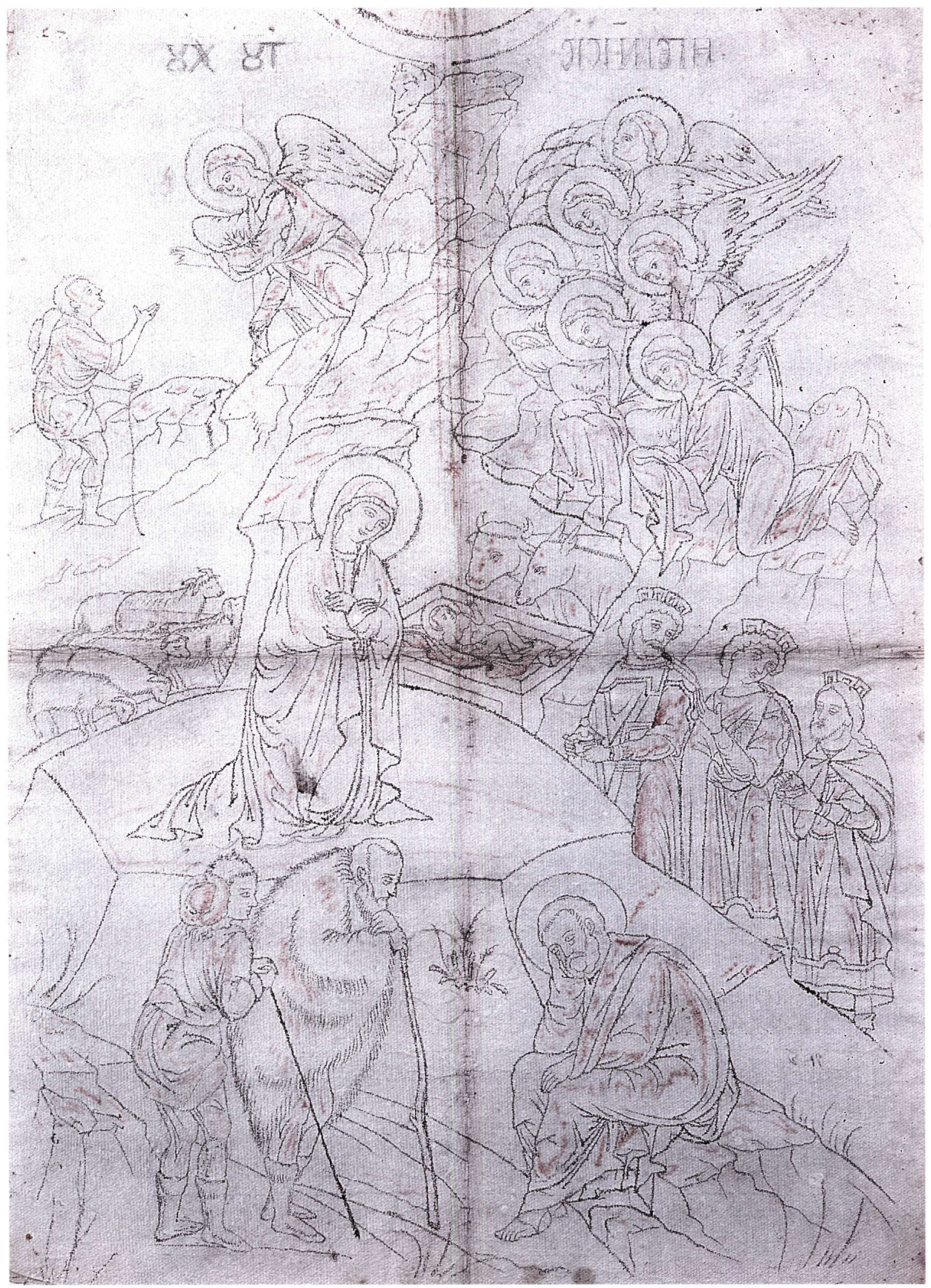




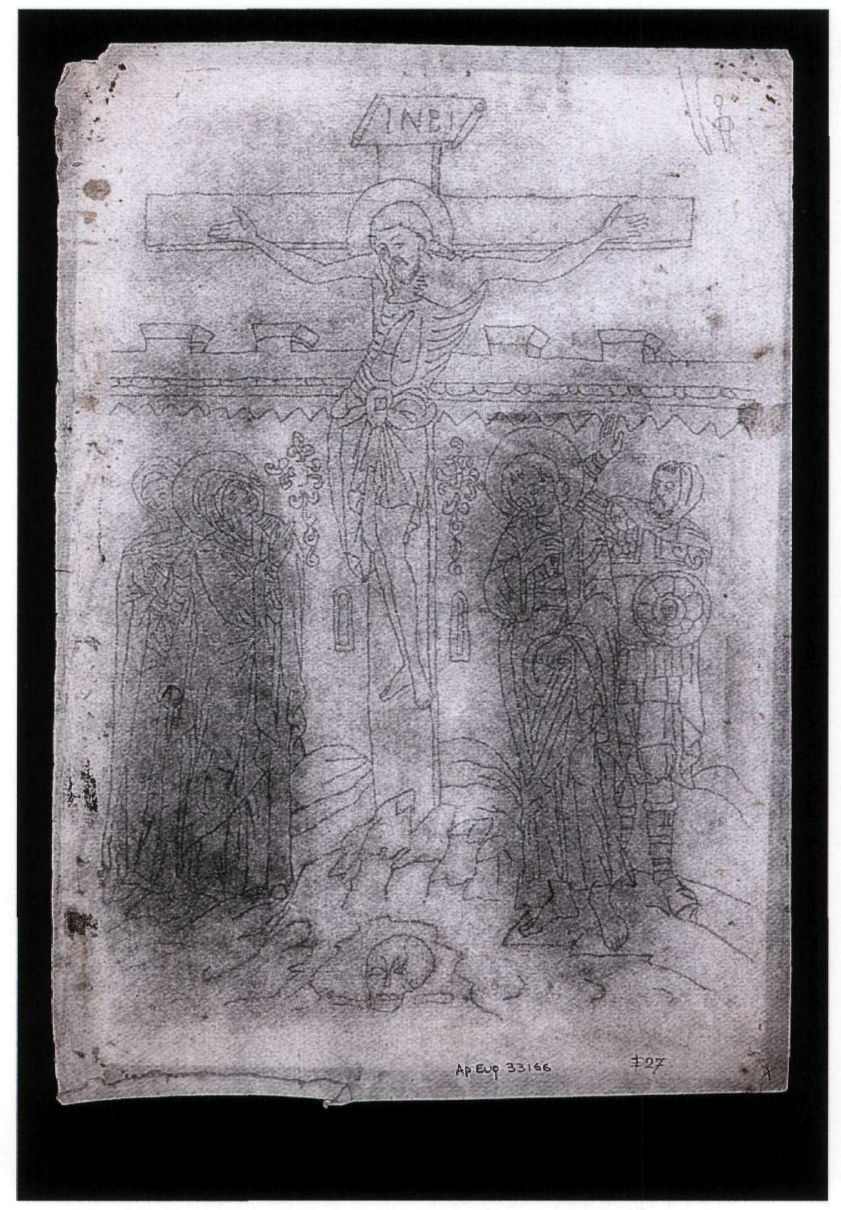

Fig. 5. Pricked cartoon of the Crucifixion. Athens, Benaki Museum 33166 (photo: K. Manolis).

has taken place in Greece, and inter alia it will be of assistance in the establishing a database to which other samples can be added at a later date.

Apart from the date, the study of watermarks enables us to identify the mill where every sheet of paper was manufactured, and by extension it sheds light on the conditions of paper distribution in the Greek world and more generally on the commercial activities of the period. It would appear that watermarks are very frequently preserved, and when they can be accurately dated they provide the most reliable terminus post quem for establishing the date of working drawings. Since an icon can be copied at any time, even centuries after its execution, the only method of determining when a drawing was produced is by dating its paper from the watermark. For this reason a considerable amount of

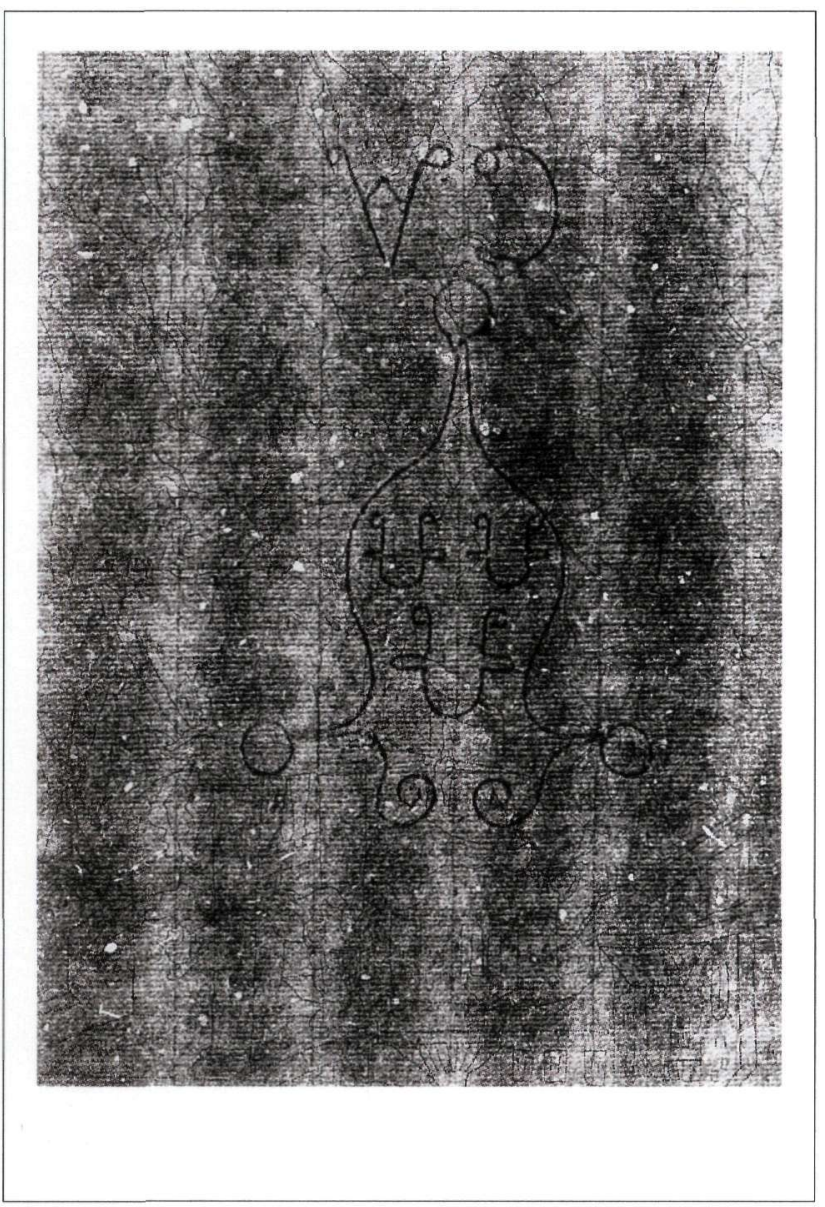

Fig. 6. Watermark record in scale 1:2 from the pricked cartoon of the Massacre of the Innocents. Athens, Benaki Museum 33243 (photo: K. Manolis).

time has been spent on recording watermarks, with invaluable help to date from the archaeologists Panoraia Benatou and Yannis Varalis and the paper conservation specialists Sofia Kollarou, Argyro Chiladaki and Flora Stefanou.

Their first attempts at recording were made by the traditional method of placing the design over a lightbox and tracing the watermark on transparent paper. The second involved scanning by computer, and this produced interesting results. But by far the most faithful reproductions of working drawings are those made with the use of beta-radiography (fig. 6) and this stage of the project is still in the course of development. ${ }^{14}$ Valuable assistance in this area was given by Janet Lang of the British Museum, who has been applying the beta-radiography method over a number of years and 
was therefore the most suitable person to introduce us to its use. The examination of the Benaki Museum's watermarks, which originally took place in the laboratories of "Demokritos", the National Centre for Scientific Research, and subsequently in those of the National Research Foundation, received financial assistance from the Cultural Foundation of the Greek Industrial Development Bank (ETVA).

\author{
Maria Vassilaki \\ Associate Professor of Byzantine Art, University of Thessaly \\ Research Associate, Benaki Museum
}

\section{NOTES}

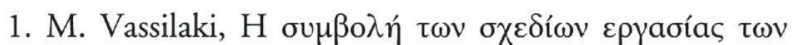

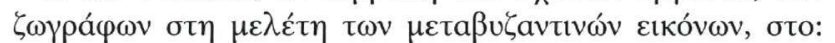

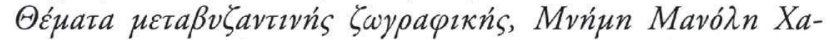
$\tau \zeta$ ndákn, Proceedings of a Symposium, Institute of Neohellenic Research-Christian and Archaeological Society, Athens, 28-29 May 1999 (forthcoming).

2. The Painter's Manual of Dionysius of Fourna, translated into English by Paul Hetherington (London 1974) 5.

3. The garlic juice allowed the colour to penetrate the paper more easily.

4. The text of Akotantos' will was published by $M$.

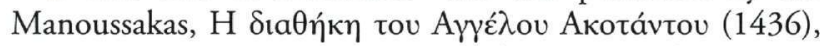

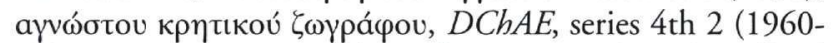
61) 139-50. A copy of the will is preserved in the official books of the Acts of the Duke of Crete (A. S. V. Duca di Candia, b. 11: Atti Antichi 2, notebook 25bis [1453-1457] fasc. 6 [last]). It was originally undated. The date (26 April) and the indiction (14th) were added at the end of the text by the notary Ioannis Vatatzes, to whom Akotantos brought the will for certification. The text was republished by $M$.

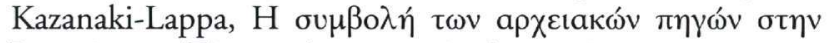

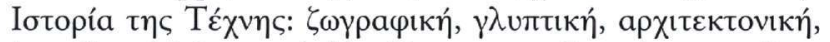

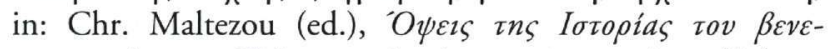

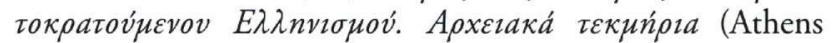
1993) 456-58, doc. no. 3. For the most recent publication

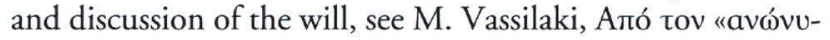

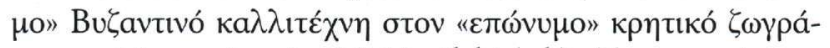

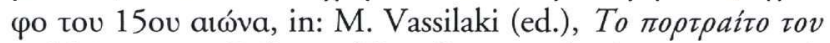

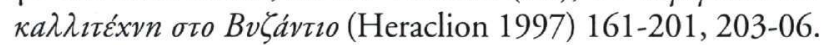

5. The date 1436, suggested by Manoussakas, is based on the evaluation of direct data in the will and indirect information in other documents.

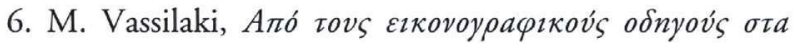

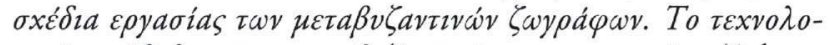

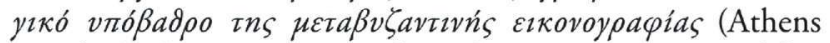
1995) 60-61; Drawing in the Italian Renaissance Workshop (exhibition catalogue, Fr. Ames-Lewis, J. Wright [eds], Victoria and Albert Museum, London 1983).

7. Vassilaki, ibid., passim.

8. M. Chatzidakis, Musée Bénaki, BCH 68-69 (1944-45)
424.

9. L. Bouras, Working Drawings of Painters in Greece after the Fall of Constantinople, in: From Byzantium to El Greco (exhibition catalogue, Royal Academy of Arts, London 1987) 54-56.

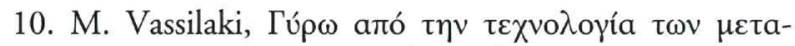

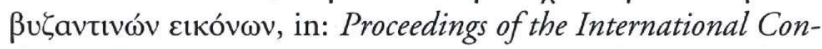

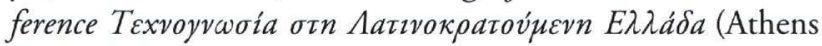
2000) 195-206; M. Vassilaki, Workshop Practices and Working Drawings of Icon-Painters, in: E. HausteinBartsch, N. Chatzidakis (eds), Greek Icons. Proceedings of the Symposium in Memory of Manolis Chatzidakis, Recklinghausen 1998 (Athens, Recklinghausen 2001) 71-75.

11. On infra-red reflectography, see J. R. J. van Asperen de Boer, Infra-red Reflectography: A Contribution to the Examination of Earlier European Paintings (Ph. D., University of Amsterdam 1970); id, Infra-red Reflectograms of Panel Paintings, Studies in Conservation 14 (1967) 98-118. On the use of the method for the works of Raphael, C. Cristensen, Examination and Treatment of Paintings by Raphael at the National Gallery of Art, in: J. Beck (ed.), Raphael before Rome (=Studies in the History of Art 17, 1986) 47-54. Infrared reflectography was also used to examine the works of Piero della Francesca and Raphael in the National Gallery (London): J. Dunkerton, S. Foister, D. Gordon, N. Penny, Giotto to Dürer, Early Renaissance Painting in the National Gallery (New Haven, London 1991) 168-69 figs 225-28.

12. For information on watermarks generally, see the entry in The Dictionary of Art 32 (London 1996) 908 s. v. Watermarks (Shirley Millidge).

13. Cf. the 4 volume work by C. M. Briquet, Les Filigranes: Dictionnaire historique des marques du papier des leur apparition vers 1282 jusqu' en 1600 (Geneva 1907).

14. The procedures and the results of this method are analysed in Ariane de La Chappelle, A. Le Prat, Les relevés de filigranes. Watermark records. I relievi di filligrane. Atelier de restauration du département des Arts graphiques, Musée du Louvre (Paris 1996), which assembles the findings of the research programme on watermarks at the Louvre. 


\section{MAPIA BA $\Sigma$ I $\Lambda$ AKH}

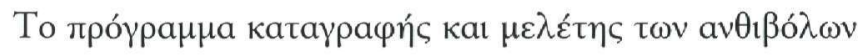

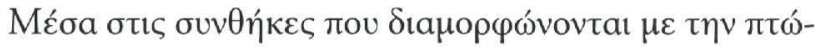

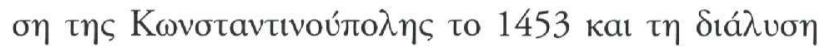

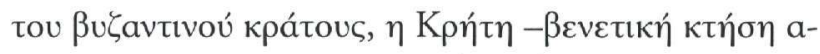

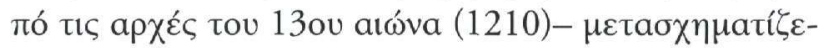

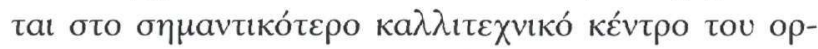

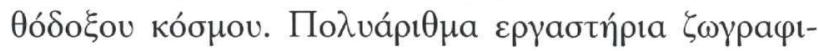

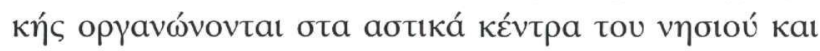

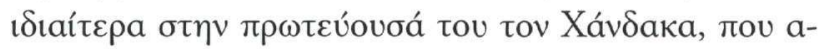

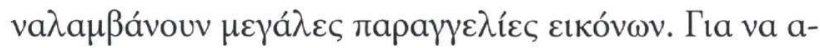

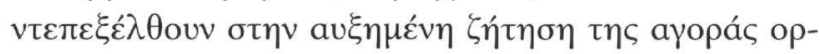

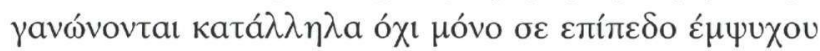

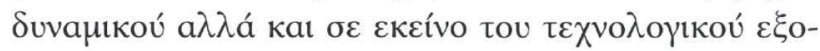

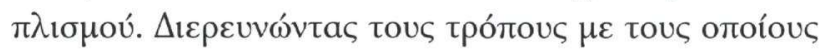

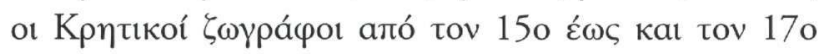

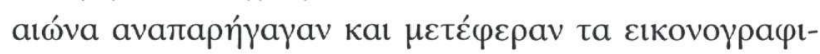

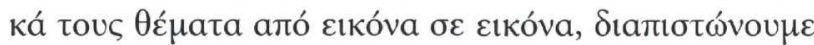

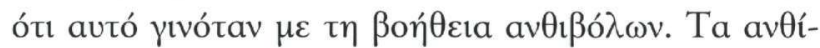

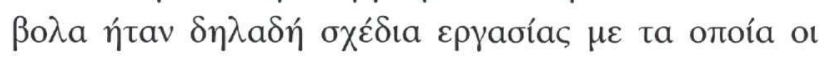

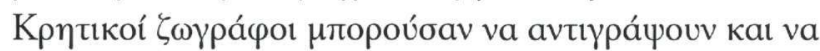

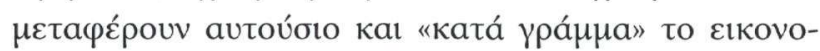

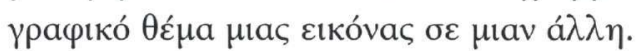

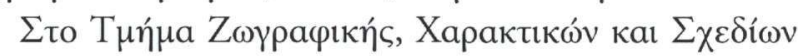

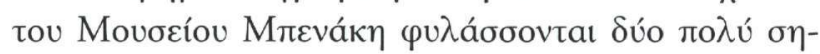

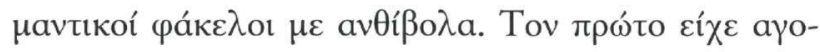

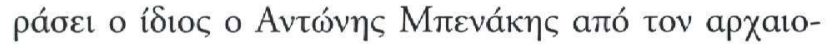

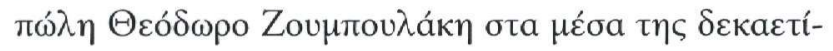

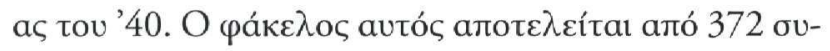

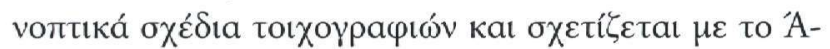

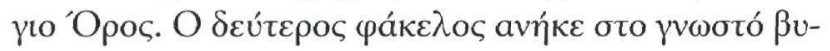

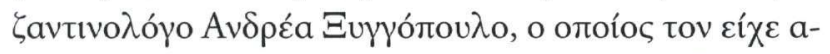

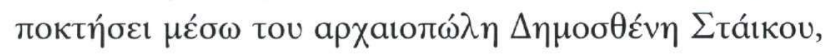

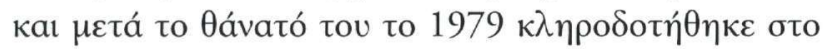

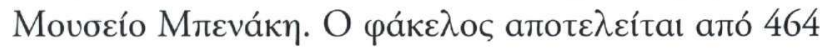

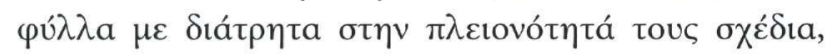

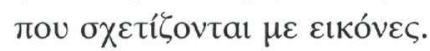

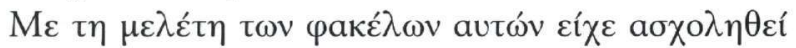

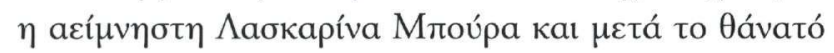

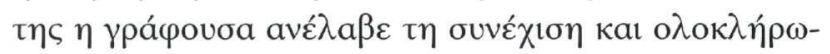

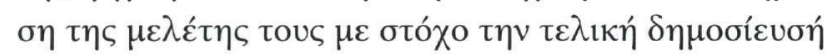

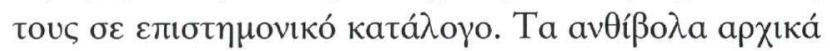

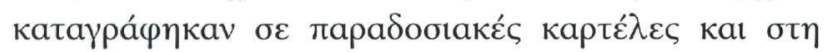

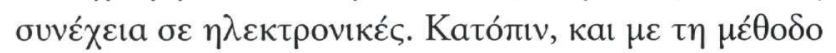

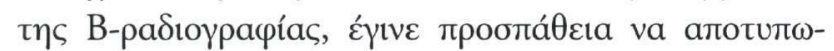

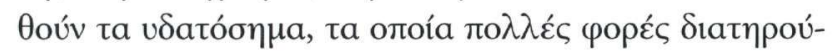

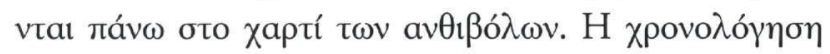

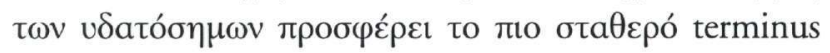

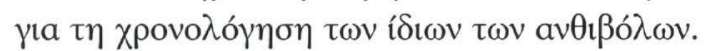

